\title{
MIEJSCE I ROLA KOBIETY W ŻYCIU I MYŚLI SW. GRZEGORZA WIELKIEGO Od teorii biblijnej do praktyki codziennego życia VI wieku
}

Jan Paweł II, wielki następca św. Grzegorza, w swym liście apostolskim zatytułowanym Mulieris dignitatem, tyczącym godności i powołania kobiety, zawarł następującą myśl: „Godność kobiety i jej powołanie - odwieczny temat refleksji ludzkiej i chrześcijańskiej - nabrały w ostatnim okresie szczególnej wyrazistości"1.

Pytając o ów „ostatni okres”, o którym mówi Ojciec Święty, warto mieć na uwadze zarówno procesy społeczne zapoczątkowane już w XIX wieku, a związane $\mathrm{z}$ dążeniami do emancypacji kobiet i zrównania w prawach z mężczyznami, jak też ewolucję refleksji teologicznej dotyczącej kobiety ${ }^{2}$. Naturalnie, wszelki wysiłek zmierzający do zmian ma swoje pozytywne aspekty. Problem jednak rodzi się, gdy zostaje naruszona równowaga. Dotyczy to, oczywiście, także refleksji nad miejscem i posłannictwem kobiety. Refleksja ta bowiem, jak się dziś okazuje, wybiera różne tory swego rozwoju i nie zawsze muszą one oznaczać postęp. Czasami okazują się być zatruwaniem dzisiejszej kobiety poglądami, które prowadzą raczej do jej metafizycznego samobójstwa, niż do ukazania godnego miejsca w społeczeństwie, świecie, czy chrześcijaństwie.

Nie jest jednak moim zadaniem ani przedstawianie współczesnych zjawisk, ani ich ocena. Nie jestem ani socjologiem, ani etykiem. Zainteresowani mogą sięgnąć po specjalistyczną literaturę, tworzoną przez osoby bardziej kompetentne ${ }^{3}$. Zawiłości jednak współczesnego czasu, które dostrzec możemy nawet bez wchodzenia w fachowe dywagacje, skłaniają do stawiania pytań o to, jak sprawy miały się przeszłości. „Historia magistra vitae est” - poucza nas Cyceron $^{4}$. I ma rację. Zwróćmy się przeto ku owej nauczycielce życia i spytajmy ją o posłannictwo kobiety w myśli św. Grzegorza Wielkiego (540-604).

${ }^{1}$ Mulieris dignitatem 1, AAS 80 (1988) 1653, thum. pol. w: Wybór listów Ojca Swiętego Jana Pawła II, t. 1, Kraków 1997, 80.

${ }^{2}$ Por. R. Gibellini, La teología del siglo XX, Santander 1998, 445-476.

${ }^{3}$ Por. tamże, s. 606-608.

4 Cicero, De oratore II 9, 36. 
Pozostaje jeszcze kwestia: dlaczego VI wiek i dlaczego ten akurat autor? Po pierwsze dlatego, że ten czas jest już czasem krzepnięcia zawartości teologicznego tygla. Jest to raczej czas przedstawiania tego, czego dokonano, niż czas wielkich dyskusji. Na horyzoncie widać już zapowiedź średniowiecznych syntez. Autor zaś, oprócz tego, że jest jednym z największych papieży w historii Kościoła i - jak powie Gilson - „ostatnim przedstawicielem odchodzącej starożytnej kultury rzymskiej”" , jest równocześnie znawcą życia i ludzkich ścieżek, doświadczonym tak w sprawach świeckich, jak i w życiu mistycznym. Pytanie zatem o pozycję kobiety w VI wieku skierowane do tego akurat świętego, to pytanie o wizerunek kobiety wykreowany w ogóle przez całą chrześcijańską starożytność. Być może pozwoli to na danie jakiejś odpowiedzi autorom, którzy tendencyjnie ukazują wyrwane z kontekstu zdania Ojców Kościoła, w odłączeniu od całości wykładu i kontekstu kulturowego epoki, brzmiące rzeczywiście dziwnie $^{6}$. Wystarczy tu odwołać się chociażby do zdania św. Augustyna, który w komentarzu do Księgi Rodzaju wyraził pogląd, iż kobieta mężczyźnie pomóc może jedynie w rodzeniu dzieci, bo do wszystkiego innego bardziej pomocny jest raczej drugi mężczyzna ${ }^{7}$.

Chcąc mieć w miarę spójny obraz zagadnienia warto przyjrzeć się obrazowi kobiety, jaki pozostawił nam w swoich pismach św. Grzegorz. Ciekawostką jest, że w przeciwieństwie do wielu wcześniejszych pisarzy ${ }^{8}$, ten akurat nie stworzył żadnego systematycznego traktatu na temat kobiety, co nie oznacza, iż problem traktował pobieżnie. Zostawił wiele słów dotyczących owego problemu, porozrzucał je jednak po całej swojej twórczości, poczynając od komentarzy biblijnych, na czele ze słynnymi Moraliami do Księgi Hioba, a skończywszy na

${ }^{5}$ E. Gilson, Historia filozofii chrześcijańskiej w wiekach średnich, thum. S. Zalewski, Warszawa 1987, 101. Św. Grzegorz żył w latach 540-604, pełnił już za młodu poważne obowiązki, m.in. był prefektem Rzymu. W wyniku duchowego przełomu porzucił karierę urzędniczą, założył kilka klasztorów, a w jednym $\mathrm{z}$ nich sam osiadł poszukując życia kontemplacyjnego. Wyrwany $\mathrm{z}$ klasztornego zacisza został diakonem oraz apokryzjariuszem (legatem) na dworze cesarskim w Konstantynopolu. Po śmierci Pelagiusza II został wybrany papieżem. Urząd ten pelnił od 590 roku. Zasłynął jako mistrz duchowości a równocześnie trzeźwy rządca Kościola, ewangelizator i gorliwy pisarz. Zmarł w roku 604, słusznie przez potomność nazwany wielkim. Szerzej na temat jego osoby Por. S. Boesch Gajano, Gregorio Magno. Alle origini del Medioevo, Roma 2004; J. Czuj, Papież Grzegorz Wielki, Warszawa 1948; R. Markus, Grzegorz Wielki, tłum. P. Nehring, Warszawa 2003; V. Recchia, Gregorio Magno, DPAC II 1698-1707. Doskonałą pomoc stanowią także: R. Godding, Bibliografia di Gregorio Magno (1890-1989), Roma 1990; F. S. D'Imperio, Gregorio Magno. Bibliografia per gli anni 1980-2003, Firenze 2005; S. Longosz, Sw. Grzegorz Wielki w polskich studiach. Materialy bibliograficzne, VoxP 24 (2004) t. 46-47, 705-714.

${ }^{6}$ Por. np. M. Agnosiewicz, Miejsce $i$ wizerunek kobiety $w$ chrześcijaństwie, http:// www.racjonalista.pl/kk.php/s\%2C473.

7 Por. Augustinus, De Genesi ad litteram IX 5, zob. A.D. Fitzgerald, Diccionario de san Agustín, Burgos 2001, 914.

${ }^{8}$ Wystarczy tu wspomnieć chociażby takich autorów, jak Tertulian (De cultu feminarum), św. Jan Chryzostom (De virginitate). 
obfitej korespondencji, największej, jaka dotarła do nas z czasów wczesnego chrześcijaństwa ${ }^{9}$. Przyglądając się tym tekstom, zajmiemy się po pierwsze teorią, czyli obrazem i symboliką kobiety najpierw w Biblii, później w hagiografii. Aspekty owe są istotne $z$ tej przyczyny, iż po pierwsze to właśnie one wytyczały Grzegorzowy sposób patrzenia na kobietę, po drugie ukazują pozycję kobiety w świadomości wybitnego teologa tamtego czasu. Następnie zapytamy o praktykę relacji między wielkim Biskupem Rzymu, a osobami płci żeńskiej, czyli spróbujemy wydobyć wizerunek kobiety Grzegorzowi współczesnej, pytając o różne sposoby realizacji jej powołania w świecie i Kościele; w końcu spróbujemy rzecz krótko podsumować.

\section{GRZEGORZOWA WIZJA KOBIETY BIBLIJNEJ}

Nie ulega wątpliwości, iż Biblia stanowi dla Grzegorza instrument podstawowy i swoisty drogowskaz, wytyczający kierunki zarówno jego życia duchowego, jak i refleksji intelektualnej. W nauczaniu, jak prawie każdy Ojciec Kościoła, jest przede wszystkim komentatorem Bożego słowa ${ }^{10}$. W tymże zaś słowie na poczesnym miejscu, pośród innych kobiet, widzi Maryję ${ }^{11}$. I tu jednak nie można mówić o jakiejś mariologii systematycznej, w wydaniu naszego autora jest to raczej ukierunkowana kerygmatycznie refleksja o charakterze pastoralnym. Jako taka ma za swój główny cel zbliżenie człowieka do chrześcijańskiego misterium i pogłębienie jego życia duchowego.

Kim jest dla Grzegorza Maryja? Przede wszystkim cisną się tu trzy tytuły, których najchętniej używa wielki pontyfik, mianowicie: Boża Rodzicielka (Matka), (zawsze) Dziewica i Stużebnica. Obok nich znajdujemy także takie, jak Błogostawiona oraz Pani. Terminy te mają nie tylko znaczenie kurtuazyjne, odnoszą się bowiem do rzeczywistości. Dla Grzegorza, który jest wiernym sługą Kościoła i strażnikiem jego nauki, świętym jawi się równocześnie to, co Kościół wypracował we wcześniejszych wiekach i oficjalnie orzekł. Skoro zaś, że jak sam zaznaczył, naukę pierwszych soborów szanuje na równi z księgami Ewangelii $^{12}$, siłą rzeczy także i wykształconą już mariologię przyjmuje za swoją. Ta zaś widzi Maryję dokładnie jako Dziewicę i Matkę ${ }^{13}$. Zasługą zatem Grzegorza jest nie tyle wprowadzenie czegoś nowego, co autorytatywne potwierdzenie

${ }^{9}$ Por. J. Czuj, Papież Grzegorz Wielki, Warszawa 1948, 244.

${ }^{10}$ Według M. Starowieyskiego „teologia Ojców Kościoła to po prostu studium Pisma św.”, por. Swięty Ambroży, TP 32 (1978) nr 20 (14 V), 4-5.

11 Por. M. Doucet, La Vierge Mère de Dieu dans la théologie de saint Grégoire le Grand, BLE 84 (1983) 163-177.

12 Por. Epistulae I 24, CCL 140, 32, 358-359: ,[...] sicut sancti evangelii quattuor libros, sic quattuor concilia susciperet venerari me fateor".

${ }^{13}$ Wystarczy tu wspomnieć terminologię i orzeczenia takich soborów, jak Konstantynopolitański I (Denz. 150), Efeski (Denz. 251, 252), Chalcedoński (Denz. 301), czy Konstantynopolitański II (Denz. 422, 423). 
wcześniejszego dorobku ${ }^{14}$. Dla nas zaś istotne jest, że najważniejsza spośród biblijnych kobiet stanowi ideał dziewicy, co Grzegorz potwierdza choćby w opowiadaniu o Muzie, dziewczynce, która doświadczyła objawienia Maryi, przewodniczącej towarzystwa dziewic. Czytamy o tym w Dialogach:

„Pewnej nocy ukazała się jej we śnie Matka Boża, Maryja, zawsze Dziewica i pokazała dziewczynki w jej wieku, ubrane na biało. Muza pragnęła przyłączyć się do nich, lecz nie miała odwagi. Błogosławiona Maryja, zawsze Dziewica, zapytała ją, czy chciałaby pójść razem z nimi i żyć służąc jej"15.

Oczywiste jest, że Muza ochoczo udzieliła pozytywnej odpowiedzi. Finałem opowieści jest przejście Muzy do wieczności, po trzydziestu dniach przygotowań, o czym nasz autor pisze następująco:

„[...] oddała ducha i opuściła swe dziewicze ciało, aby zamieszkać razem ze świętymi dziewicami" 16 .

Ideał ten oczywiście nie jest Grzegorzowym pomysłem, buduje go zarówno na wzorcach biblijnych, jak i patrystycznych. Wspomnieć tu możemy choćby nauczanie Cypriana z Kartaginy, Grzegorza z Nyssy czy Jana Chryzostoma ${ }^{17}$.

Przejdźmy jednak dalej, by spotkać się z Marią Magdaleną. Problemem w naszym przypadku jest identyfikacja osoby. Okazuje się bowiem, że to nie kto inny, jak właśnie św. Grzegorz winien jest powstania poglądu trwającego niemal do dzisiejszych czasów, że mówiąc o Marii Magdalenie, o jawnogrzesznicy i o Marii z Betanii, ma się na myśli tę samą osobę ${ }^{18}$. Pozostawmy jednak tę kwestię, gdyż nie dotyczy ona bezpośrednio naszego tematu. Dla nas ważniejsze będzie co innego, a mianowicie fakt, iż Maria, grzesznica, jest osobą, która doświadcza miłości Chrystusa i która na tę miłość odpowiada swoją miłością. Nasz autor powiada:

„Tu trzeba ważyć, jak wielka siła miłości rozjaśniała umysł tej niewiasty, która nie odchodziła od grobu nawet wówczas, kiedy odchodzili stamtąd uczniowie. Doszukiwała się Go, skoro Go dotąd nie znalazła; poszukując z oddaniem płakała; a rozpalona ogniem Jego miłości, płonęła pragnąc Tego, którego uznała za odebranego. Dlatego jej samej tylko przypadło Go wówczas oglądać - jej, która pozostała by szukać"19.

Kobieta zatem, nawet grzesznica, może służyć, według Grzegorza, za wzór duchowy. Warto o tym pamiętać. Więcej, owa grzeszna kobieta urasta do

14 Por. Doucet, La Vierge Mère de Dieu, s. 163.

${ }_{15}$ Dialogi IV 18, 1, SCh 265, 70, tłum. E. Czerny, ŹM 23, 304.

${ }^{16}$ Tamże IV 18, 3, SCh 265, 70, ŹM 23, 306.

${ }^{17}$ Por. C. Tibilletti, Vergine - Verginità - Velatio, DPAC II 3559-3563.

${ }_{18}$ Por. J. Radermaker, Marie, DEB 795.

${ }^{19}$ Homiliae in Evangelia II 25, 1, CCL 141, 205, tłum. Oficyna Wydawnicza VIATOR : Sw. Grzegorz Wielki, Homilie na Ewangelie, Warszawa 1998, 211-212. 
miary symbolu osoby nawróconej, otwartej na miłość Bożą i kochającej Boga. Pozwala to Grzegorzowi na rozwinięcie paraleli $z$ jednej strony pomiędzy Magdaleną i Ewą, a $\mathrm{z}$ drugiej między grzesznicą $\mathrm{z} Ł \mathrm{k} 7,37 \mathrm{n}$, namaszczającą stopy Jezusa olejkiem, a Kościołem. W pierwszym przypadku, słyszymy interpretację sceny przy grobie Zmartwychwstałego:

„Oto wina rodzaju ludzkiego została usunięta tam, skąd wyszła. Bo że w raju niewiasta wpoiła w mężczyznę śmierć - od grobu niewiasta zwiastuje mężczyznom życie i opowiada słowa swego Ożywiciela ta, co opowiadała była słowa śmiercionośnego węża. Jak gdyby Pan nie słowami, ale wydarzeniami mówił rodzajowi ludzkiemu: $\mathbf{z}$ tej samej ręki, $\mathbf{z}$ której został wam podany trunek śmierci, podejmijcie czarę życia" ${ }^{20}$.

\section{W drugim zaś przypadku Grzegorz stwierdza:}

„Nas zatem - nas - wyraża ta niewiasta, jeśli po grzechach całym sercem nawracamy się do Pana, jeśli naśladujemy żałość jej pokuty. [...]. Jeśli bowiem dokonujemy czynów prawych, poprzez które zraszamy Kościół wonią dobrej slawy, to cóż dla Ciała Pańskiego czynimy, jeśli nie olejek na nie wylewamy? ${ }^{21}$.

Naturalnie, postacie Matki Bożej i Marii Magdaleny nie wyczerpują tematu Grzegorzowej symboliki kobiety biblijnej. Ekspert moralności nie mógł pominąć i samej Ewy. Oczywiście, jako symbolu słabości:

„Gdy bowiem odwieczny wróg nie może wtargnąć do silnego serca, szuka związanych $z$ nim słabych osób i jakby po przystawionej drabinie wchodzi na wysokie mury. Tak oszukał Adama przez towarzyszącą mu niewiastę. Tak, gdy pozabijał dzieci błogosławionemu Jobowi, zostawił słabą niewiastę aby przynajmniej przez słowa niewiasty mógł przenikać do jego serca, skoro sam żadną miarą tego nie zdołal"22.

Lekkie to słowa w porównaniu z Tertulianowymi, w których Ewa nazwana jest m.in. „bramą diabła”23. Na poziomie zatem tej teorii kobieta dla naszego autora jawi się jako obraz słabości. Choć, jeśli zechcemy drążyć nadal temat Ewy, znajdziemy tam też typologię Kościoła, który rodzi się przez śmierć Jezusa, jak Ewa przez sen Adama ${ }^{24}$.

Cóż jeszcze symbolizuje kobieta? Grzegorz, który od momentu nawrócenia skłaniał się raczej ku kontemplacji, niż ku działaniu, kobiety biblijne wykorzystuje także, by ukazać relację tych dwóch sposobów życia, w czym zresztą naśladuje takich wcześniejszych autorów, jak Hilary, Ambroży, Augustyn,

${ }^{20}$ Tamże II 25, 6, CCL 141, 212, VIATOR s. 219.

21 Tamże II 33, 5, CCL 141, 293, VIATOR s. 299.

22 Epistulae 5, 44, CCL 140, 333, tłum. J. Czuj: Sw. Grzegorz, Listy, II, Warszawa 1954, 124.

23 Tertullianus, De cultu feminarum $1,1$.

24 Por. In Ezechielem I 6, 15. 
czy Jan $\operatorname{Kasjan}^{25}$. Naszemu autorowi posłużą w tym celu postacie Marty i Marii ${ }^{26}$, żon Jakuba - Racheli i Lei ${ }^{27}$ oraz córek Saula - Mikal i Merab ${ }^{28}$.

Biblijne postacie kobiece niosą w sobie także typologię Kościoła. Wspomnieliśmy ten fakt przy okazji odwołania do Ewy. Dla otrzymania w miarę kompletnego obrazu musimy jeszcze przywołać przede wszystkim oblubienicę z Pieśni nad Pieśniami, wspominaną już Rachelę ${ }^{29}$, żony Elkany: Annę - matkę Samuela, która przedstawia Kościół, i Peninnę - symbol synagogi ${ }^{30}$.

Warto zatrzymać się przy tym ostatnim przykładzie. Grzegorz stwierdza wyraźnie, iż oblubienica, jak i jej towarzyszki obrazują Kościół:

„W sposób najdoskonalszy oblubienicą jest Kościól, Oblubieńcem zaś Pan. Dziewczętami, które towarzyszą oblubienicy, są dusze rozpoczynające drogę doskonałości i wzrastające w gorliwości. Towarzyszami Oblubieŕca są albo aniołowie, którzy czasami ukazują się ludziom, przychodząc do Niego, albo ci doskonali mężowie w Kościele, którzy poznali, że mają głosić ludziom prawdę. Ale ci, którzy są czy to dziewicami, czy towarzyszami, jednocześnie wszyscy są oblubienicą, ponieważ jako całość wszyscy są Kościołem"31.

Dochodzi tu jeszcze, jak zauważyliśmy, obraz dziewcząt jako symbolu ludzkiej duszy. Nie wdajemy się w bardziej gruntowne ukazanie kwestii oblubienicy, której medytację Grzegorz opiera na poglądach wcześniejszych twórców, jak Orygenes, Augustyn czy Aponiusz ${ }^{32}$, ale warto wiedzieć, iż nawet części jej ciała mają dla naszego autora swoje znaczenie eklezjologicznej alegorii ${ }^{33}$. Piękną alegorię znajdujemy także w opisie trzech córek Hioba, które oznaczają cnoty teologalne ${ }^{34}$, choć równocześnie są symbolem ludzkiej słabości ${ }^{35}$.

${ }^{25}$ Por. S. Frank, Actio und Contemplatio bei Gregor dem Grossen, TThZ 78 (1969) 283n; S. Rosik, Aktywność i kontemplacja jako formy życia chrzescijańskiego wedtug nauki św. Grzegorza Wielkiego, RTK 23 (1976) z. 3, 35-49; S. Sojka, Przedchrześcijańskie ,actio" $i$ „contemplatio" $a$ „vita activa" $i$,vita contemplativa" $u$ św. Grzegorza Wielkiego, VoxP 6 (1986) z. 10, 17-39.

${ }^{26}$ Por. Lk 10, 38-42; Epistulae I 5; VII 22; In I Regum V 178; Moralia in Job VI 37, 61.

${ }^{27}$ Por. Rdz 29, 9-30; Epistulae I 5; In I Regum I 64; IV 157; V 179; Moralia in Job VI 37, 61; In Ezechielem II 2, 10.

${ }^{28}$ Por. 1 Sm 14, 49-50; In I Regum 5, 175-180.

29 Por. Moralia in Job XXX 25, 73.

${ }^{30}$ Por. 1Sm 1, 2. 20; In I Regum Prol. 1; I 8; I 85; II 29. Poglądy swe sw. Grzegorz czerpie także z wcześniejszych opinii, np. od św. Augustyna (O państwie Bożym XVII 4). Obrazem synagogi jest dla Grzegorza także żona Hioba, por. Moralia in Job XIV 44, 52.

31 In Cantica Canticorum 10, CCL 144, 13.

${ }^{32}$ Por. J.M. Petersen, The influence of Origen upon Gregory's Exegesis of the Song of Songs, StPatr 18 (1985) t. 1, 343-347.

${ }^{33}$ Por. Moralia in Job II 52, 82 - usta jako obraz przepowiadania Kościoła; In Ezechielem II 4, 6 - kolana symbolem ojców duchowych; Regula pastoralis I 11; In Ezechielem I 11, 7 - nos jako symbol czujności Kościoła; Moralia in Job XIX 12, 19 - piersi jako obraz okresów rozwoju Kościoła; Moralia in Job XXIV 8, 17 - piersi jako obraz pogan i Żydów, którzy wspólnie weszli do Kościola Chrystusowego.

${ }^{34}$ Por. Moralia in Job XXXV 16, 42.

35 Por. tamzie XXXV 19, 46. 
Oprócz wymienionych, znajdujemy w twórczości Grzegorza jeszcze kilkadziesiąt odwołań do różnych postaci kobiecych spotkanych w Biblii. I tak wspomnieć można dziesięć ewangelicznych panien ${ }^{36}$, którym autor nasz poświęcil osobną homilię ${ }^{37}$ i kilka fragmentów swoich Moraliów ${ }^{38}$ oraz fragment komentarza do Księgi Królewskiej ${ }^{39}$. Nie trzeba chyba tłumaczyć, jaki ładunek moralny niosą owe panny - roztropne to obraz ludzi umartwiających się, duchowych, skłonnych do wysiłku i wyrzeczeń, dążących do szczęścia wiecznego; przeciwnie nierozsądne - reprezentują osoby ignorujące potrzebę czynienia dobra, idące drogą potępienia.

Wśród pozostałych przedstawicielek żeńskiej grupy biblijnej warto tu jeszcze wspomnieć Aksę - obraz duszy kierującej ciałem ${ }^{40}$, Dinę - obraz duszy lekkomyślnej ${ }^{41}$, Batszebę - symbolizującą stare Prawo, ale i przypominającą siedem darów Ducha Świętego ${ }^{42}$, Rebekę - typ Kościoła ${ }^{43}$ lub Bożej łaski ${ }^{44}$, Sarę - obraz czujności cielesnej i Hagar - symbol tych, którzy chcą deprecjonować ludzi Kościoła ${ }^{45}$.

Spośród kobiet anonimowych zaznaczmy jeszcze córki Izraelitów z $1 \mathrm{Sm} 8$, 13 - raz mogą one symbolizować słabość człowieka, inny raz płodność, jeszcze inny -napełnionych Duchem Świętym ${ }^{46}$, zależnie od aktualnej potrzeby. Pokornych pokutników w łonie Kościoła będzie reprezentować kobieta, która dotknęła frędzli płaszcza Chrystusowego ${ }^{47}$.

Podsumowując, rzec można, że przykłady kobiet biblijnych służą św. Grzegorzowi do snucia refleksji moralnej, duchowej oraz eklezjologicznej i z tego punktu należy patrzeć na ich interpretację. W tym kontekście zrozumiałe jest, że czasem można zobaczyć kobietę jako symbol negatywny, ale też obficie obecna jest symbolika pozytywna. Należy zauważyć, że Grzegorz jest generalnie otwarty na kobietę w swych teoretycznych dywagacjach, a występujące niekiedy niejasności należy zrzucić na karb wcześniejszych wpływów i tradycyjnego, rzymskiego wychowania. Ukazane tu spojrzenie będzie kształtowało myślenie i spojrzenie papieża Grzegorza na kobietę tak w osobistej relacji, jak w teoretycznych twierdzeniach.

\footnotetext{
36 Por. Mk 25, 1-13.

${ }^{37}$ Por. Homiliae in Evangelia I 12.

38 Por. Moralia in Job VIII 44, 85; VIII 45, 74; XXXIV 23, 53.

${ }^{39}$ Por. In I Regum III 156.

${ }^{40}$ Por. Joz 15, 16-19; Epistulae VII 23.

${ }^{41}$ Por. Rdz 34, 1-4; Regula pastoralis III 29.

${ }^{42}$ Por. 2Sm 11, 2-5; Moralia in Job III 28, 55.

${ }^{43}$ Por. Rdz 24, 61-66; Moralia in Job I 15, 21; XXXV 16, 38.

${ }^{44}$ Por. Rdz 27; In Ezechielem I 6, 3.

45 Por. Rdz 16-18; Moralia in Job IX 66, 196; In I Regum II 111.

${ }^{46}$ Por. In I Regum IV 58.

${ }^{47}$ Por. Łk 8, 43-47; Moralia in Job III 20, 27; XX 17, 43.
} 


\section{KOBIETA HAGIOGRAFII I LEGENDY}

Terenem, na którym teoria kobiety, odczytana przez Grzegorza w Biblii, jest rozwijana, a równocześnie przekładana na język życia chrześcijańskiego, jest płaszczyzna hagiografii i legendy. Nasz autor miał szczęście wzrastać w atmosferze świętości i pod opieką świętej kobiety, swojej matki - Sylwii ${ }^{48}$. Zaskakujące jest, że Grzegorz wspomina matkę zaledwie raz ${ }^{49} \mathrm{i}$ to $\mathrm{w}$ tle historii śmierci innej świętej ze swej rodziny, ciotki ze strony ojca, Tarsylii.

Wobec powyższego, do dziś nie wyjaśnionego faktu, przejdźmy do owej ciotki Tarsylii i jej, również świętej, siostry. Z jednej z Grzegorzowych homilii dowiadujemy się o trzech siostrach jego ojca, św. Gordiana ${ }^{50}$. Były to wspomniana św. Tarsylia, św. Emiliana oraz Gordiana. Wszystkie podjęły styl życia dziewiczego:
„Wszystkie $\mathrm{z}$ jednym zapałem oddały się stanowi duchownemu, w jednym i tym samym czasie zostały konsekrowane, a żyjąc według surowej reguły, prowadziły życie wspólne w swoim wlasnym domu. W miarę, jak trwały w tym duchownym stanie, poczęły Tarsylia i Emiliana przez codzienne postępy wrastać w ukochaniu swego Stwórcy i trwając tu jedynie cieleśnie, duchem codziennie przechodziły ku sprawom wiecznym" ${ }^{\text {. }}$.

Pewnie nie uszło nam uwadze, że brak tu trzeciej ciotki, Gordiany. Ta, niestety, zeszła na złą drogę. A właściwie, patrząc z naszego punktu widzenia, czy rzeczywiście na złą? Po śmierci obu świętych sióstr, jak czytamy we wspomnianej homilii:

„Gordiana zorientowała się, że pozostała sama; znieprawienie jej wyrosło i co przedtem skrywala w pragnieniu myśli, to potem wyrosło wskutek znieprawionego działania. Albowiem przepomniawszy bojaźni Pańskiej, przepomniawszy wstydu i szacunku, przepomniawszy stanu poświęconego, wzięła sobie potem za męża dzierżawcę swoich majątków"s2.

Swięty biskup Rzymu opisuje jeszcze cudowne okoliczności śmierci Tarsylii i Emiliany w homilii i we fragmencie Dialogów ${ }^{53}$, słuch natomiast po Gordianie zaginął. I choć Grzegorz już nic o niej nie mówi, to jednak cały ten moment jest wymowny, bo oto zostaje nam ukazany ideał i najlepsze miejsce dla chrzes-

${ }^{48}$ Por. J.B. Proja, Silvia, BS XI 1082; A. Stępniewska, Sylwia - matka papieża Grzegorza Wielkiego, VoxP 23 (2003) t. 44-45, 363-373.

49 Por. Homiliae in Evangelia II 38, 15, CCL 141, 375, VIATOR s. 391: „w tej właśnie godzinie jej zgonu, stanęło wokól jej łóżka wiele mężczyzn i kobiet, między którymi była też moja matka".

${ }^{50}$ Por. tamze II 38.

51 Tamże II 38, 15, CCL 141, 374, VIATOR s. 390.

52 Tamże, CCL 141, 376, VIATOR s. 392.

53 Por. Dialogi IV 17, 1-3. 
cijańskiej kobiety, ideał, którego zrealizowanie było marzeniem, niestety niespełnionym $^{54}$, samego Grzegorza - dziewictwo i życie monastyczne.

Obraz ideału dopełniają też inne święte, jak choćby św. Scholastyka ${ }^{55}$ ze słynnego fragmentu Dialogów. Siostra św. Benedykta, „wszechmogącemu Panu poświęcona już od najwcześniejszego dzieciństwa" ${ }^{56}$, która żyła opodal klasztoru swego brata i która spotykała się z nim raz na rok, by wieść pobożną dysputę. Zdarzyło się, że razu pewnego pragnęła pozostać dłużej z bratem, lecz ten nie chciał łamać reguly, nie pozwalającej na pozostanie na noc poza klasztorem. Wynik był taki, iż po chwili modlitwy świętej kobiety zerwała się taka wichura, iż Benedykt nie miał szans wyjścia na zewnątrz. ${ }^{57}$ I choć słynny uczony A. de Vogüé powie, iż Scholastyka reprezentuje tu obraz miłości, to zapamiętać też warto, iż przede wszystkim jest to mniszka prowadząca życie kontemplacyjne.

W tychże samych Dialogach Grzegorz ukazuje nam inny przykład mniszki św. Gallę, córkę konsula Symmacha ${ }^{58}$. Ta młoda wdowa:

„miała wszystkiego w bród i zarówno młody jej wiek, jak i bogactwo mogly ją skłonić do powtórnego małżeństwa [...] wolała połączyć się z Bogiem małżeństwem duchowym, które zaczyna się w smutku, lecz dochodzi do wiecznych radości, niż poddać się małżeństwu cielesnemu, które zawsze rozpoczyna się radością i zmierza do smutnego końca" ${ }^{\text {59 }}$.

Ideał duchowych zaślubin zrealizowała w klasztorze św. Piotra, a zmarła w cudownej atmosferze, uprzedzona przez patrona swego klasztoru ${ }^{60}$.

54 Epistulae I 5, CCL 140, 6, Czuj I s. 6: „Umiłowałem piękno życia kontemplacyjnego, jak Rachelę niepłodną, lecz widzącą i piękną; i chociaż ono przez swój spokój mniej rodzi, jednak subtelniej widzi światło. Nie wiem jednak, jakim prawem przyłączyła się do mnie w nocy Lia, to znaczy życie czynne, płodne, ale chore na oczy, mniej widzace, aczkolwiek płodniejsze. Usiłowałem siedzieć z Marią u stóp Pana, słuchać Jego słów, a oto zmuszony jestem z Martą posługiwać w sprawach mniej ważnych i krzątać się koło wielu rzeczy".

${ }_{55}$ Por. G.M. Colombas, El milagro de santa Escolástica. Dos lecturas de san Gregorio Magno. Dialogos II 33 y 34, NV 11 (1981) 29-37; P.A. Cusack, St. Scholastica: myth or real Person?, DRev 92 (1974) 145-159; A. Linage Conde, En el centenario de santa Escolástica. Lo eterno femenino en la vida de san Benito, NV 10 (1981) 181-204; A. Pantoni, Un venerando santuario cassinese: la chiesa di santa Scolastica o del „colloquio”, „Benedictina” 1 (1947) 25-41; tenże, Sulla localitá del convegno annuale di s. Benedetto e s. Scolastica, e sul monastero de Piumarola, „Benedictina” 15 (1968) 206-228; J.H. Wasbrough, St. Gregory's Intention in the Stories of St Scholastica and St Benedict, RBen 75 (1965) 145-151; A. De Vogủe, La rencontre de Benoît et de Scholastique. Essai d'interprétation, „Revue d'Histoire de la Spiritualite” 48 (1972) 257-273. Pelniejszy spis literatury można odnaleźć w: Godding, Bibliografia di Gregorio Magno 1890-1989, n. 1354-1364.

56 Por. Dialogi II 33, 2.

57 Tamże II 33, 3-4.

58 Por. G.B. Proja, Santa Galla, patrizia romana, nei Dialoghi di san Gregorio Magno, RSB 23 (1954) 94-109; A. Quacquarelli, Galla nei Dialoghi di Gregorio Magno, w: Giornata di studi su santa Galla, Roma 1991, 17-26.

59 Dialogi IV 14, 1.

60 Por. tamże IV 14, 4-5. 
Obraz tej grupy kobiet uzupełniają święte mniszki Herundo, Redempta i Romula ${ }^{61}$. Herundo była pustelnicą w Górach Prenesteńskich, Redempta zaś jej uczennicą, podobnie, jak znowu pod jej kierownictwem rozwijała się Romula i jeszcze jakaś osoba nieznana $z$ imienia. To właśnie Romula, złożona na wiele lat paraliżem, w końcu została zabrana do nieba przy cudownym akompaniamencie damskich i męskich głosów ${ }^{62}$. Przy tej okazji nasz autor chwali też ubóstwo, ale czyż nie jest pierwszoplanowym jej stan życia? Dodać tu możemy jeszcze przykład wspomnianej już Muzy, tak pragnącej życia w towarzystwie niebiańskich dziewic ${ }^{63}$.

Wobec pierwszoplanowej roli stylu dziewiczo - monastycznego, jaką odkrywamy w dziele tego biskupa Rzymu, możemy się pokusić o postawienie, być może zbyt daleko idącej tezy, że nie wspomina on swojej matki ze względu na fakt, iż była żoną i matką, przez co ginęła w cieniu takich szwagierek, jak Emiliana i Tarsylia. Grzegorz, który niewątpliwie matkę kochał, nie widział po prostu potrzeby mówienia o niej, skoro tuż obok mial dwa nader jaskrawo świecące przykłady chrześcijańskiej doskonałości. Oczywiście, ideał życia kobieta może wypełnić w inny sposób, dlatego też św. Grzegorz wielką estymą darzy np. męczennice. Wystarczy wspomnieć przykłady św. Felicyty ${ }^{64}$ i Agnieszki ${ }^{65}, \mathrm{z}$ których pierwszej poświęcił cała homilię ${ }^{66}$, drugiej zaś fragment homilii ${ }^{67}$. Męczennica zwycięża słabość płci ${ }^{68}$. Więcej, w kobiecym ciele Grzegorz dostrzega jednak męskie serce ${ }^{69}$.

Wracając jednak do ideału monastycznego i uwzględniwszy, że wedle Grzegorza „można ponieść męczeństwo bez zewnętrznych cierpień"70 , można chyba mniemać, że najlepszym środowiskiem do realizacji tej szczytnej drogi jest droga mnisza. Byłoby to może owo męczeństwo in occulto, o którym także wspomina nasz niestrudzony autor ${ }^{71}$. Kobieta zatem święta to przeważnie kobieta realizująca ideał monastyczny i męczeństwo. Poza pewnymi wyjątkami, bo w opowiadaniach Świętego Papieża spotykamy też na poły legendarne postacie kobiet, które są przykładami miłości macierzyńskiej ${ }^{72}$, małżeńskiej ${ }^{73}$,

${ }^{61}$ Por. A. Amore, Romola, Redenta ed Erudine, BS XI 348-349.

${ }^{62}$ Por. Homiliae in Evangelia II 40, 11; Dialogi IV 16.

${ }^{63}$ Por. Dialogi IV 18, 1-3.

${ }^{64}$ Por. F. Carrafa, Felicitá BS V 605-608; V. Saxer, Felicitá, DPAC I 1350.

65 Por. E. Josi, Agnese, BS I 382-407; V. Saxer, Agnese, DPAC I 84-85.

${ }^{66}$ Por. Homiliae in Evangelia I 3.

67 Por. tamze I 11, 3.

68 Por. tamże I 3, 4.

${ }^{69}$ Por. Homiliae in Evangelia I 3, 3, CCL 141, 22, VIATOR s. 47: „Rozważcie, bracia najdrożsi, jak męskie serce w kobiecym ciele".

70 Dialogi III 26, 8, CCL 260, 370, ŹM 23, 249.

71 Por. tamże III 26, 7, CCL 260, 370, ŹM 23, 249: „Istnieją [...] dwa rodzaje męczeństwa: jedno tajemne, drugie jawne. Jeśli nawet nie ma zewnętrznych prześladowań, jeśli dusza gotowa jest cierpieć i płonie pragnieniem męczeństwa, ma tajemną zasługę męczerístwa".

72 Por. tamże I 2.

${ }^{73}$ Por. tamże III 17, 3-5. 
oddanej służby (tu akurat chodzi o opiekunkę młodego jeszcze św. Benedykta) ${ }^{74}$, czy w koncu żarliwej modlitwy ${ }^{75}$.

Pośród zagadnień hagiograficzno-legendarnych nie sposób pominąć jednego jeszcze, dziwnego przypadku, mianowicie opowieści o koniu, który, wcześniej należąc do pewnej kobiety, po wypożyczeniu go papieżowi św. Janowi I (523-526), nie chciał już wozić swej dawnej pani, ,jakby z pogardą okazywał, że po tym, jak nosił kapłana, kobiety nosić nie może" ${ }^{, 76}$. Jeszcze jeden odblask schematów społecznych, które od czasu do czasu jednak dochodziły u Grzegorza do głosu.

\section{KLASZTOR, MAŁŻEŃSTWO I WDOWIEŃSTWO - RÓŻNE DROGI KOBIETY}

W pismach Grzegorza Wielkiego znajdujemy generalnie powyższe trzy, ukazane w tytule niniejszego rozdziału, sposoby realizacji powołania kobiety. W świetle dotychczasowych przemyśleń nie będzie chyba problemu z odgadnięciem, do którego sposobu życia znajdziemy najwięcej referencji. Oczywiście, życie monastyczne zajmuje poczesne miejsce, teologia małżeństwa okazuje się praktycznie szczątkowa. Podobnie ma się sprawa z problemem wdowieństwa. $\mathrm{Z}$ przyczyn dyscyplinarnych trochę miejsca zajmuje również kwestia relacji między kobietami a duchownymi.

1. Życie monastyczne. Po tzw. edykcie mediolańskim, uwalniającym chrześcijan od prześladowań, z jednej strony znikła generalnie możliwość fizycznego męczeństwa zaś z drugiej rozpoczął się napływ większych mas ludzi do Kościola, co także zaowocowało, niestety, spadkiem poziomu wiary i moralności zarówno owych mas, jak i kleru. Próbą odpowiedzi, m.in. na ten problem, było powstanie monastycyzmu, męczeństwa bez przelewu krwi i szukania doskonałości na wzór Chrystusa i świętych ${ }^{77}$.

W ten właśnie nurt wpisuje się św. Grzegorz Wielki, pierwszy w historii papież - mnich. Powyżej wspomnieliśmy już o ideale życia monastycznego. Teraz słów kilka o jego wypełnieniu przez kobietę wspomnianą w dziele naszego autora. Zaznaczyć trzeba, iż nie jest tu łatwo zdefiniować kobietę konsekrowaną. Używa on odnośnie niej różnych określeń, jak np. sacra virgo, famula Dei, ancilla Dei, sanctimonialis virgo, sanctimonialis femina, religiosa femina. Problemem jest jednak to, iż Grzegorz używa niektórych z tych termi-

74 Por. tamże II 1.

75 Por. tamże III 25, 1-2.

76 Tamże III 2, 2, SCh 260, 266, ŹM 26, 200.

77 Por. G.M. Colombas, El monacato primitivo, Madrid 1998, V. Desprez, Poczq̨tki monastycyzmu, thum. J. Dembska, ŹM 21-22, Kraków 1999. 
nów także w odniesieniu do niektórych pobożnych kobiet. ${ }^{78}$ Osoby, które wybrały życie dziewicze, zamieszkiwały przeważnie w siedzibach zwanych monasterium virginum lub congregatio virginum. ${ }^{79}$ Wcześniej jednak dziewice żyły, jak podkreśla Tibilletti, w świecie. ${ }^{80}$ Colombas mówi nawet, że w trzech pierwszych wiekach, ,żyły w swych własnych domach, nie nosiły habitu ani specjalnego stroju, jako że nie można za taki uważać welonu, którym zwykle nakrywały głowę. Uczestniczyły w życiu społecznym, brały udział w weselach, chodziły do łaźni" ${ }^{81}$. Dobrze, lecz mamy wiek VI i powstały już klasztory. Lecz czy wszystkie dziewice żyły w klasztorach? Przecież wspomniane już ciotki Grzegorza mieszkały jednak w swoim własnym domu ${ }^{82}$. Pozostaje przyjąć, że był to po prostu jeden ze sposobów prowadzenia życia dziewiczego, zaś dom taki stawał się quasi-klasztorem.

Życie mniszki to życie oddane Bogu, co określa termin vita sanctimonialis $^{83}$. który tłumaczyć możemy jako życie monastyczne, czy życie pobożne ${ }^{84}$. Mało tego, życie takie, to życie niebiańskie ${ }^{85}$. Osoba, która podjęła taki styl życia, to postać czcigodna. Dlatego św. Scholastyka nazwana jest raz sanctimonialis femina ${ }^{86}$, innym razem venerabilis femina ${ }^{87}$.

Grzegorz w rozproszonych fragmentach swych pism daje świadectwo organizacji ówczesnych klasztorów żeńskich, analogicznej do męskich ${ }^{88}$. Na czele klasztoru stoi zwykle abbatissa, co w języku polskim oddajemy zwykle przez „ksieni”. Czasem może to być jednak praeposita, choć to termin w analizowanych przez nas pismach niecodzienny ${ }^{89}$. Grzegorz prowadzi korespondencję $\mathrm{z}$ wieloma ksieniami. Można wspomnieć choćby Juliannę, Florę, czy Teklę ${ }^{90}$. Kto może być ksienią? Nasz autor twierdzi, że dziewica przynajmniej sześć-

${ }^{78}$ Por. np. Epistulae XII 14.

${ }^{79}$ Por. V. Recchia, Monache e monasteri femminili nelle opere di Gregorio Magno, w: tegoż, Gregorio Magno Papa ed esegeta biblico (col. Quaderni di „Invigilata Lucernis”, 4), Bari 1996, 288289: „Per designare la singola monaca Gregorio usa i nessi «sacra virgo», «famula Dei», «ancilla Dei», «sanctimonialis virgo», «sanctimonialis femina» e perfino la più comprensiva espressione «religiosa femina». [...]. Per i monasteri si passa dal generico «sanctus Dei ovilis», alle determinate espressioni «monasterium virginum» e «congregatio virginum»".

${ }^{80}$ Por. C. Tibillettii, Vergine - Verginità - Velatio, DPAC II 3559-3563.

81 Colombas, dz. cyt., s. 32.

${ }^{82}$ Por. Homiliae in Evangelia II 38, 15.

83 Por. Dialogi, 3, 14, 1.

${ }^{84}$ Por. E. Bianchi - R. Bianchi - O. Lelli, Dizionario illustrato della lingua latina. Firenze $1994,1403$.

85 Por. Dialogi III 21, 1.

86 Por. tamże II 33, 2-3, SCH 260, 230-232.

${ }^{87}$ Por. tamże II 34, 1, SCh 260, 234.

${ }^{88}$ Por. F. Antonelli, De re monastica in Dialogis S. Gregorii Magni, „Antonianum” 2 (1927) 409-424.

89 Por. Epistulae VII 27.

90 Por. tamże I 46; III 17; IX 54. 
dziesięcioletnia, dobrego życia i obyczajów ${ }^{91}$. Przypadek jednakowoż Tekli z neapolitańskiego klasztoru św. Maryi zdaje się wskazywać, że Grzegorz nie widzi konieczności, by ksienią zostawała dziewica. ${ }^{92}$ Może to jednak odosobniony przypadek, chociaż Kodeks Justyniana, mówiąc o przełożonej, wspomina także o dziewicy lub innej kobiecie ${ }^{93}$. Być może również, że papież akceptuje model zastany, w dyrektywach swych jednak próbuje wprowadzać normy bardziej rygorystyczne.

List do Respekty, przełożonej jakiegoś klasztoru w Galii, uświadamia nam, iż dla zostania ksienią należało wpierw zostać wybraną przez wspólnotę, potem ustanowioną przez miejscowego biskupa ${ }^{94}$. Nie znajdujemy praktycznie norm dotyczących innych mniszek, choć napotykamy na ślad pewnego rodzaju nowicjatu, jak to ma miejsce w przypadku wspomnianych już Hirundo, Redempty i Romuli ${ }^{95}$. Mniszki, choć zgromadzone w swoim klasztorze, jednak podlegają biskupowi ${ }^{96}$. Biskup winien dbać o porządek, doglądać wyborów ksieni, które mają się znowu odbywać zgodnie $\mathrm{z}$ wolą Kościoła, reprezentowanego przez biskupa i w jedności z papieżem. Oprócz tego biskup ma wspierać wspólnotę, powinien nauczać i dbać o poziom duchowy ${ }^{97}$.

Droga monastyczna, to służba Boża ${ }^{98}$. Mniszka, mimo odosobnienia, powinna jednak być otwarta na inne osoby, winna gromadzić innych do owej Bożej służby, jej postawa winna odwodzić innych od grzechu. W ten sposób, przyblizając innych do Boga, sama doń się zbliża ${ }^{99}$. W końcu, w miarę możności, mniszka powinna dzielić się $\mathrm{z}$ biednymi ${ }^{100}$. Kobieta, która decyduje się na życie monastyczne, podejmuje życie modlitwy i uwielbienia Boga ${ }^{101}$. Ramy dla właściwego wypełniania ideału stanowią pokój, posłuszeństwo i cisza ${ }^{102}$, prostota serca $^{103}$, a także ubóstwo ${ }^{104}$.

91 Por. tamże IV 11.

92 Por. tamże IX 54.

93 Cod. Iust. I 3, 47 (46), 2: „Haec omnia et in reverendissimis feminis aut virginibus, quae piis monasteriis praesunt". Może jednak słowo praesunt nie musi tu być koniecznie rozumiane jako „kieruja"?

94 Por. Epistulae VII 12.

95 Por. Homiliae in Evangelia II 40, 11; Dialogi IV 15, 1-2.

96 Por. Epistulae VII 12.

97 Por. tamże IX 115.

98 Por. tamże II 46.

99 Por. tamże VII 27.

${ }^{100}$ Por. Dialogi IV 14, 3.

101 Por. Epistulae IX 115. Szerzej na ten temat: B. Calati, La preghiera nella tradizione monastica dell'alto medioevo (da S. Gregorio Magno all'epoca carolingia); w: C. Vagaggini - G. Penco (ed.), La preghiera nella Bibbia e nella tradizione patristica e monastica, Roma 1964, 523-566.

${ }^{102}$ Por. Dialogi IV 16, 2; Homiliae in Evangelia II 40, 11.

103 Por. Dialogi IV 14.

104 Por. Homiliae in Evangelia II 40, 11. Obszerniej na temat ubóstwa: A. De Vogüe, La pauvreté dans la monachisme occidental du Ive au VIII' siècle, CCist 46 (1984) 177-185. 
Mniszka tamtego okresu, to także osoba posiadająca czasem nadzwyczajne dary duchowe, jak np. moc wyrzucania demonów ${ }^{105}$. Równocześnie jednak to ktoś żyjący na tym świecie i podlegający normom. Pośród tych godne miejsce zajmuje reguła. W błędzie byłby jednak ten, kto chciałby szukać konkretnych objaśnień na temat reguł monastycznych, używanych w klasztorach czasów Grzegorza w jego twórczości. Grzegorz wspomina o regule, ale nie mówi, ani jaka to reguła, ani jakie zawiera komponenty ${ }^{106}$. Przecież nawet słynne ciotki „żyły wedle surowej reguły"107. Problemem jednak pozostaje, że w owym czasie było już rozpowszechnionych kilka regu1 ${ }^{108}$.

Obok reguły tym, co charakteryzuje osobę konsekrowaną, jest odpowiedni strój. Jak nas zapewnia F. de B. Vizmanos, „dopóki IV wiek nie wszedł w swój dojrzały okres, nie pojawia się na Zachodzie aluzja do jakiegoś specjalnego stroju, który charakteryzowałby dziewice Chrystusowe" ${ }^{109}$. Jesteśmy jednak w VI wieku i dlatego nie dziwi, iż rzecz uległa zmianie, o czym świadczy choćby przypadek Redempty ${ }^{110}$. Habit to znak życia konsekrowanego ${ }^{111}$. Na marginesie można dodać, że także do zadań biskupa należało błogosławienie habitu mniszki (benedictio vestimentorum virginum) przy okzji jej ustanowienia (consecratio $^{112}$ ), zaś sam obrzęd nałożenia stroju zwał się velatio i ten właśnie termin przekazuje nam biskup Rzymu ${ }^{113}$.

Wobec tego, iż życie zakonne było tak bliskie sercu naszego autora, powstaje pytanie, co się dzieje, gdy ktoś taki stan porzuci? Odnajdujemy na ten temat kilka tekstów. Przede wszystkim u Grzegorza występują różne drogi sprzeniewierzenia się powołaniu zakonnemu. Z klasztoru można np. uciec, jak zdarzyło się córce pewnego szlachetnie urodzonego Tuliana. W dwóch listach tej sprawy tyczących Grzegorz wylewa cały swój gniew, nazywając biskupa miejsca, w którym zaistniało zdarzenie, niedbałym (neglegens) oraz tępym (hebes) ${ }^{114}$, zaś tamtejszego defensora oskarża o brak przezorności. ${ }^{115}$

105 Por. Dialogi III 21, 2-3.

106 Por. Epistulae IV 9.

107 Homiliae in Evangelia II 38, 15, CCL 141, 374, VIATOR s. 390.

108 Warto mieć na uwadze przynajmniej reguly św. Augustyna, Cezarego z Arles, Kolumbana, Benedykta oraz Pachomiusza i Bazylego, por. E. Dekkers, Saint Grégoire et les moniales, CCist 46 (1984) 26; A. de Vogüe, La Règle du Maître et les Dialogues de saint Grégoire, RHE 61 (1966) 44-76.

${ }^{109}$ F. De B. Vizmanos, Las vírgines cristianas de la Iglesia primitiva, Madrid 1949, 268.

110 Por. Dialogi IV 16, 1.

111 Por. Recchia, Monache e monasteri femminili, s. 301.

112 Por. G. Escudero, Verginitá e Liturgia. La consecrazione delle vergini, Roma 1963; A. Paladini, De benedictione et consecratione virginum, EL 49 (1935) 441-445; R. Metz, La consécration des vierges dans l'Église Romaine: Étude d'histoire de la Liturgie, Paris 1954.

113 Por. Epistulae IV 24.

114 Por. tamże VIII 8.

115 Por. tamże VIII 9. 
Sprawa sie kończy nakazem sprowadzenia owej mniszki do klasztoru i na powrót odziania w strój monastyczny.

$\mathrm{Z}$ ostrą reakcją spotyka się także uwiedzenie. Odpowiedzią na nie w pewnym przypadku jest ekskomunika i nakaz pokuty w klasztorze dla obojga ${ }^{116}$, co jest i tak małą karą, jako że np. Kodeks Justyniana przewidywał w przypadku uwiedzenia dziewicy nawet ścięcie delikwenta ${ }^{117}$. Podobnie małżeństwo z mniszką w dziele Grzegorzowym jest uważane za wielką zbrodnię i bezbożność ${ }^{118}$. Innym problemem jest też nieuczciwość niektórych kobiet, przejawiająca się np. w używaniu wspólnych dóbr do zdobycia stanowiska ${ }^{119}$, umiłowanie tego świata ${ }^{120}$, czy nawet stultiloquium, czyli nieopanowanie języka ${ }^{121}$.

$\mathrm{Na}$ koniec warto także nadmienić, iż Grzegorz stoi na stanowisku, by kobieta mogła swobodnie wybierać życie monastyczne ${ }^{122}$; gorzej sprawa się ma w przypadku, gdy kobieta chce $\mathrm{z}$ niego zrezygnować, jak zaznaczyliśmy wyżej na przykładzie córki Tuliana. Poza tym jest otwarty na potrzeby klasztorów i mniszek w różnych trudnych sytuacjach, zarówno w zakresie materialnym, dyscyplinarnym, jak i duchowym ${ }^{123}$.

$\mathrm{W}$ jednym zdaniu podsumowania można powiedzieć, że $\mathrm{z}$ jednej strony Grzegorz jest wielkim orędownikiem monastycyzmu żeńskiego, z drugiej zaś jest zdania, że nie wszystkim kobietom on odpowiada, a problemy, które spotykamy w pismach Swiętego są analogiczne do dziś obserwowanych.

2. Małzeństwo. O ile kwestia życia dziewiczego pojawia się w analizowanej spuściźnie wielkiego biskupa Rzymu VI wieku w formie i ilości dość pokaźnej, o tyle małżeństwo nie znajduje w niej wiele miejsca. Możemy się dowiedzieć, że jest ono święte (sanctum coniugium), ukierunkowane na zrodzenie potomstwa, oraz niższe od życia kontemplacyjnego; przynależy ono raczej do ludzi cielesnych, jak kontemplacja - do ludzi duchowych ${ }^{124}$. Kobieta w małżeństwie to przede wszystkim matka i żona oraz członki ciała, którego głową jest mężczyzna ${ }^{125}$. I właściwie niewiele można powiedzieć na ten temat oprócz tych kilku słów.

3. Wdowieństwo. Także i stan wdowy, od dawna poważany w Kościele ${ }^{126}$, nie zajmuje zbyt wiele miejsca $\mathrm{w}$ corpus gregorianum. Wiadomo, że wdowa

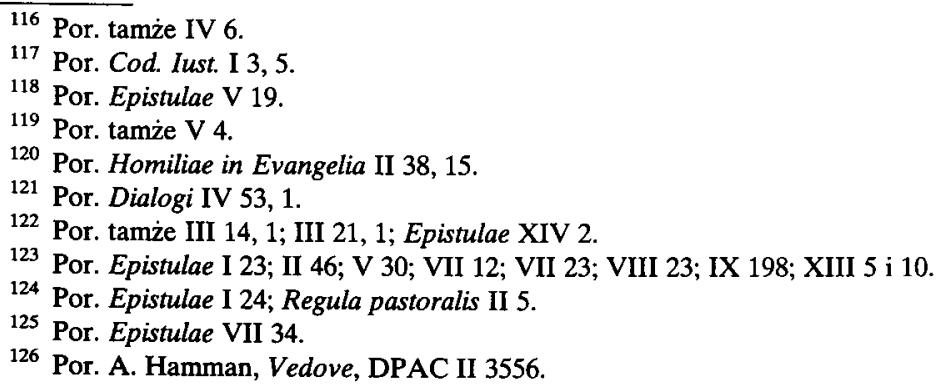


godna jest opieki i pomocy ze strony Kościoła ${ }^{127}$. Uzasadnieniem tego jest potrzeba naśladowania Chrystusa Pana, co podkreślal Grzegorz następująco:

„Jeśli według świadectwa Pisma św. sam Pan nasz oświadcza, że jest małżonkiem wdów i ojcem sierot, to i my również, którzy jesteśmy członkami Jego ciała, powinniśmy usilnie dążyć do naśladowania Glowy i zachowując sprawiedliwość udzielać pomocy sierotom i wdowom, o ile zachodzi potrzeba"128.

Opieka ta jest szczególnym zadaniem biskupa ${ }^{129}$. Pięknym przykładem takiej biskupiej troski jest przypadek Paulina z Noli ( $\dagger$ 431), o którym Grzegorz opowiada $w$ jednym $z$ dialogów: $\mathrm{z}$ miłosierdzia dla pewnej ubogiej wdowy, której syn został uprowadzony przez Wandalów, Paulin, sam już nic nie mając na okup, udał się na służbę do ich króla ${ }^{130}$. Opowiadanie to jest legendą, ale dobrze ukazuje punkt widzenia naszego autora na tę sprawę. Wiadomo, że istniały oficjalne spisy wdów i innych potrzebujących (matriculae) ${ }^{\mathbf{1 3 1}}$, o czym wspomina także nasz Święty. ${ }^{132}$ Mówi też o potrzebie uczciwości tego rodzaju kobiet:

„O ile wdowy uczciwie żyjące pozbawione są pomocy mężów, o tyle usilniej należy im udzielać opieki kościelnej”"133.

4. Kobieta a duchowni. Kwestią uzupełniającą może tu być spojrzenie na relacje pomiędzy kobietami a duchownymi. Znamy linię rozwojową idei celibatu. Mówiły o tym synody w Ancyrze (314) ${ }^{134}$, w Neocezarei (314$325)^{135}$, wiele następnych synodów i soborów, papieże i teolodzy ${ }^{136}$. Ustalenia synodalne nie zapewniały jednak same $\mathrm{z}$ siebie porządku, przeto

127 Por. Epistulae I 60 i 63; III 5; VI 35; IX 36.

128 Tamże I 60, CCL 140, 71, Czuj I 95.

129 Por. tamże I 13. Choć św. Grzegorz używa terminu sacerdotalis, to jednak list jest kierowany do biskupa Dominika $\mathrm{z}$ Centumcellae i dlatego termin ten powinien być rozumiany szeroko, obejmując także, a nawet przede wszystkim, biskupa. Zresztą i tłumacz polskiej edycji spuścizny epistolarnej naszego autora - J. Czuj - oddaje ten termin przez „biskupa”.

${ }^{130}$ Por. Dialogi III 1.

131 Por. H. Leclercq, Matricule, DACL X/2 2681-2682.

132 Por. Epistulae III 44.

${ }^{133}$ Tamże VI 35, CCL140, 409, Czuj II 211.

134 Por. Concilium Anciranum can. 10; Mansi II 518.

135 Por. Concilium Neocesariense can. 1, 7-9; Mansi II 540-541.

136 Por. H. Crouzel, Celibato del clero, DPAC I 640-641; tenże, El celibato y la continencia eclesiástica en la Iglesia primitiva: sus motivaciones, w: J. Coppens (ed.), Sacerdocio y celibato, Madrid 1972, 268-300; C. Cochini, Il celibato sacerdotale nella tradizione primitiva della Chiesa, w: G. Pittau - C. Sepe (ed.), Identitá e missione del sacerdote, Roma 1994, 166-189; G. Denzler, Das Papsttum und der Amtszölibat, I: Die Zeit bis zur Reformation, Stuttgart 1973, 27-30, 150-151; H. Gryson, Les origines du célibat ecclésiastique du premier au septieme siècle, Gembloux 1970; S. Longosz, Patrystyczna motywacja celibatu kaptańskiego, VoxP 13-15 (1993-1995) t. 24-29, 285-311 (bibliografia); E. Abbott, Historia celibatu, thum. M. Palcewicz, Wrocław 2003. 
i w czasach Grzegorza ten problem wzbudzał wiele niepokojów ${ }^{137}$. Jeśli weźmiemy pod uwagę, że nasz Autor sam był równocześnie wnukiem papieża Feliksa III ${ }^{138}$, a także pierwszym mnichem - papieżem i orędownikiem celibatu, zobaczymy, że mamy do czynienia ze sprawą na tamten czas nader dynamiczną.

W telegraficznym skrócie zaznaczyć możemy, że wszystkie referencje tyczące tego problemu, na jakie można natrafić w Grzegorzowych dziełach, są jednoznaczne: celibat obowiązuje zarówno biskupów, jak i prezbiterów oraz diakonów. Jeśli chodzi o tych pierwszych, to w tamtym czasie obowiązywały już normy zabraniające święceń biskupich mężczyznom mieszkającym z kobietami i mającym dzieci ${ }^{139}$, poza wyjątkami. Kanon 3. Soboru Nicejskiego I dawał możliwość zamieszkania $\mathrm{z}$ matką, siostrą, ciotką lub inną kobietą będącą poza podejrzeniami ${ }^{140}$. Normy normami, a życie życiem. Oto spotykamy list papieski skierowany do biskupa Feliksa z Sipontum, z którego dowiadujemy się o jego wnuku, do tego uwodzicielu ${ }^{141}$. Syna miał również biskup Jan z Syrakuz ${ }^{142}$, małą córeczkę natomiast wybrany na urząd biskupa Neapolu diakon Jan ${ }^{143}$, zaś synową (a więc $\mathrm{i}$ syna) Inportunus $\mathrm{z}$ Atelli, który scedował nawet na ową kobietę majątek kościelny ${ }^{144}$. Warto o tym pamiętać, gdyż jest to, obok ujęć teologicznych, jeden z problemów mających duży wpływ na wprowadzenie obowiązkowego celibatu w Kościele zachodnim.

Biskupowi Andrzejowi $\mathrm{z}$ Tarentu, który miał nałożnicę przed święceniami papież zaleca, iż jeśli byłby $\mathrm{z}$ nią $\mathrm{w}$ relacji intymnej także po święceniach, winien zrzec się urzędu. Uzasadnia to nie normami, a dobrem duchowym. Czy jednak napomnienia odniosły skutek? Biskup Andrzej był widać trudną postacią, skoro i tak zostaje skazany na dwumiesięczną pokutę za... obicie pewnej kobiety kijami ${ }^{145}$. Problem celibatu biskupów wraca jeszcze wiele razy, np. przy okazji Pawła z Doklei, złożonego z urzędu za złamanie zakazu. Zaobserwowany w tym przypadku opór delikwenta świadczy o braku zrozu-

${ }^{137}$ Por. Denzler, dz. cyt., s. 27-30, 150-151.

138 Por. Cochini, dz. cyt., s. 166; R. Gillet, Grégoire I le Grand, DHGE XXI 1388-1389.

139 Por. Cod. Iust. I 3, 48 (47) ; zob. też: Św. Jan Chryzostom, Przeciw duchownym mieszkającym wspólnie z dziewicami, thum. R. Sawa, wstęp S. Longosz, VoxP 13-15 (1993-1995) t. 24-29, 413-446.

140 Por. Dokumenty Soborów Powszechnych, red. A. Baron - H. Pietras, I, ŻMT 24, Kraków 2001, 29: „Wielki sobór zabronil całkowicie biskupom, prezbiterom, diakonom i wszystkim członkom stanu duchownego, zamieszkiwać z kobietą, chyba, że jest to matka, siostra, ciotka lub inna osoba stojąca poza wszelkimi podejrzeniami”. Sw. Grzegorz potwierdza dokładnie tę normę, zob. Epistulae IX 111.

141 Por. Epistulae III 42.

142 Por. tamże X 1.

143 Por. tamze X 19.

144 Por. tamze IX 143.

145 Por. tamże III 44 i 45. 
mienia tej kwestii przez przynajmniej niektórych biskupów ${ }^{146}$. Dla podkreślenia norm nasz Autor wykorzystał nawet do walki legendę, jak ta o biskupie Andrzeju z Fondi, w którego domu mieszkała mniszka i choć oboje żyli w czystości, nie ustrzegl się pokus, wynikiem czego była cudowna interwencja pewnego Żyda, który miał widzenie narady diabłów przeciw Andrzejowi, oraz usunięcie mniszki i kobiet służących $\mathrm{z}$ domu biskupiego ${ }^{147}$.

Jeśli chodzi o prezbiterów, Grzegorz mówi generalnie o tych samych zasadach, co w przypadku biskupów. Małżonka osoby wybranej na prezbitera mogła $\mathrm{z}$ nim pozostać, podobnie, jak wszystkie osoby wymienione we wspomnianym 3. kanonie Soboru Nicejskiego ${ }^{148}$. Opinia na temat zamieszkiwania $\mathrm{z}$ małżonką, jednak pod rygorem czystości, oparta jest wedle wszelkiego prawdopodobieństwa o ustalenia synodu w Elwirze (ok. 300) ${ }^{149}$. W sposób sobie właściwy, także tutaj swe poglądy nasz Autor poparł legendą: oto spotykamy jakiegoś prezbitera z Nursji, który „kochał małżonkę jak siostrę, lecz unikał, jak wroga", a w końcu nawet na łożu śmierci odepchnął ją, gdy chciała sprawdzić, czy jeszcze oddycha ${ }^{150}$.

Kobieta nie mogła także wyjść za diakona, aczkolwiek żonaty mógl zostać diakonem. Ciekawostką jest także, że wdowa po diakonie nie mogła drugi raz wyjść za mąż, mogła natomiast pozostać wdową lub wybrać życie monastyczne ${ }^{151}$. Warto zaznaczyć, że kobieta nie mogła wyjść także za subdiakona, aczkolwiek mogła $\mathrm{z}$ nim pozostać i żyć w czystości, jeśli żoną została przed jego ustanowieniem ${ }^{152}$. Jeśli jednak chciałaby być żoną kogoś $\mathrm{z}$ niższego duchowieństwa, nie miałaby większego problemu, a nawet miałaby szansę na bezpłatną ceremonię ${ }^{153}$.

Oczywistym jest, iż nie miałaby szansy na związek $\mathrm{z}$ kimś $\mathrm{z}$ kręgów monastycznych, co się rozumie samo przez się ${ }^{154}$, a o czym nasz autor traktuje szczególnie w swych Dialogach ${ }^{155}$. Oczywiście i tu życie czasem rozmija się z pobożnymi życzeniami i spotykamy związki kobiet $\mathrm{z}$ mnichami ${ }^{156}$. Papież, oczy-

146 Por. tamże XII 10; zob. też: I. Milewski, Biskupi i ich dzieci. Kilka uwag o stanie rodzinnym dostojników kościelnych we wschodnich prowincjach Cesarstwa IV i V wieku, w: Dziecko w rodzinie i spoleczeństwie. Starożytność - średniowiecze, red, J. Jundziłł - D. Żolądź-Strzelczyk, Bydgoszcz 2002, 219-233.

147 Por. Dialogi III 7, 1-8.

148 Por. Epistulae I 50.

149 Mowa o kanonie 33 tegoż synodu, por. Mansi II 12.

150 Por. Dialogi IV 12, 2-4.

151 Por. Epistulae II 50; IV 34; XIV 5.

152 Por. tamże I 42; IV 5 i 34; V 17.

153 Por. tamże IV 24; IX 90.

154 Por. A. De Vogüe, Renoncement et désir, la définition du moine dans le Commentaire de Grégoire le Grand sur le $1^{\text {er }}$ Livre des Rois, CCist 48 (1986) 64-65.

155 Por. Dialogi III 16, 5; Epistulae I 40.

156 Por. Epistulae I 40; IV 40; 
wiście, stara się temu przeciwdziałać, już to zabraniając osiedlać się kobietom blisko siedzib mniszych ${ }^{157}$, już to zabraniając kobietom uczestnictwa w mszach celebrowanych w klasztorze ${ }^{158}$.

\section{WŁADZA, SŁUŻBA, POBOŻNOŚĆ - KOBIETY RÓŻNYCH STANÓW W RELACJI Z PAPIEŻEM GRZEGORZEM}

Ogarnąwszy pobieżnym spojrzeniem dotychczasowe opinie wielkiego teologa nie sposób oprzeć się wrażeniu, że wykreowany przez niego obraz jest poniekąd ułomny. Czegoś w nim brakuje. Kobieta, o której była dotąd mowa, choć żyjąca w czasach Grzegorza i choć będąca obiektem jego szeroko rozumianej troski pasterskiej, to raczej osoba, o której pisze, ale którą przeważnie zajmuje się jakby z dystansu. Czy Grzegorz ukazał coś więcej? Otóż tak. Pośród obfitej korespondencji spotykamy pisma kierowane do kobiet różnych stanów. Na czoło wysuwa się tu korespondencja adresowana do dwóch cesarzowych i trzech królowych tamtego czasu. Mowa o Konstantynie, córce cesarza Tyberiusza II (578$582)$ i żonie jego następcy Maurycjusza (582-602). Znajomość ta, to owoc pobytu na dworze imperatora w charakterze apokryzjariusza (legata) w latach mniej więcej 579-586. Tego to okresu sięgają znajomości z pochodzącą z Rzymu Rustycjaną, jej córką Euzebią, damami dworu Dominiką i Gregorią, i siostrą Maurycjusza - Teoktystą ${ }^{159}$. Ze wszystkimi tymi osobami łączyły go dobre relacje.

Wracając do Konstantyny, musimy zwrócić uwagę na trzy listy. W pierwszym, z czerwca 594 r., odpowiada negatywnie, aczkolwiek z wielkim wyczuciem, na prośbę o relikwie św. Pawła ${ }^{160}$. Dokładnie rok później pisze kolejne dwa listy ${ }^{161}$ : pierwszy w sprawach dyscyplinarnych, drugi w kwestii używania tytułu „patriarchy ekumenicznego" przez Jana IV Postnika ${ }^{162}$. Oba listy pełne są kurtuazyjnej uprzejmości i oba są prośbą o wsparcie w problemach zależnych od cesarza ${ }^{163}$. Dysponujemy jeszcze jednym listem do cesarzowej, tym razem Leoncji, żony dawnego centuriona Fokasa, który zamordował Maurycjusza $\mathrm{i}$ jego rodzinę w 602 roku $^{164}$. List pompatyczny i pełen serwilizmu,

157 Por. tamże I 48.

158 Por. tamże V 49.

159 Por. Markus, dz. cyt., s. 24-25.

160 Por. Epistulae IV 30.

161 Por. tamże V 38;

162 Por. A. Tuilier, Grégoire le Grand et le titre de patriarche oecuménique, w: Grégoire le Grand. Actes des Colloques Internationaux du CNRS (Chantilly, 15-19 septembre 1982), Paris 1986, 69-81.

163 Por. Epistulae V 38 i 39.

164 Por. tamże XIII 40. 
podobnie, jak paralelny list do samego Fokasa ${ }^{165}$, obraz stylu epoki, dyplomacji Grzegorza i wciąż jeszcze słabości urzędu papieskiego.

I jeszcze listy do królowych: jeden do Berty, królowej Kentu ${ }^{166}$. Jest to zaledwie tylko jeden list, za to zawiera zarówno napomnienia duchowe, jak i zachętę do wsparcia misji Augustyna $z$ Canterbury ${ }^{167}$. Napomnienia nie pozostały bez odpowiedzi, skoro Augustyn utworzył silną organizację kościelną w części Anglii, zaś król Etelbert w końcu został świętym, pewnie nie bez wpływu małżonki. Zachowało się także aż dziesięć listów do Brunhildy, królowej Austrazji ${ }^{168}$. W listach tych dotyka problemów politycznych, jak i organizacyjnych Kościoła. Jest to korespondencja zażyła, świadcząca o dobrych układach pomiędzy Brunhildą a Grzegorzem, o wpływach tej kobiety oraz o zdolnościach dyplomatycznych tego sternika Kościoła ${ }^{169}$. Także do Teodolindy ${ }^{170}$, królowej Longobardów, skierował Grzegorz kilka listów. Dysponujemy dziś pięcioma, a pomijając pomyłkę kopistów, czyli powtórzenie jednego z listów, czterema $^{171}$. Szczególnie dwa ostatnie są istotne, bo zawierają wyrazy radości i podziękowania za wpływ na króla Longobardów, którego królowa skłoniła ku wierze katolickiej, oraz radość z narodzenia następcy tronu, który w tejże wierze został ochrzczony.

Wspomniane listy obrazują zarówno relacje papieża z tymi osobami, jak i ich znaczenie oraz pozycję w społeczeństwie i w Kościele, na którego życie królowe miały nawet dosyć istotny wpływ ${ }^{172}$. Obok powyższych znajdujemy także listy do Teoktysty, siostry cesarza Maurycjusza ${ }^{173}, \mathrm{z}$ których pierwszy list jest w ogóle pierwszym listem papieża Grzegorza o charakterze prywatnym. Znajdujemy też listy do Gordiany, drugiej siostry Maurycjusza i jej córki Toktysty ${ }^{174}$.

165 Por. tamże XIII 39.

166 Berta († 616) była księżniczką z linii królewskiej Chlodwiga I i jedyną córką króla Paryża Chariberta, wydana za króla Kentu, Etelberta, por. C. Cotton, Berthe, DHGE VIII 942-943. Drzewo genealogiczne można zobaczyć w: H.H. Howorth, Saint Gregory the Great, London 1912, s. LIII.

167 Por. Epistulae XI 35.

168 Brunhilda († 613) była córką króla wizygockiego Atanagilda, od 567 r. żona Sigiberta, frankijskiego króla Austrazji i wuja Berty z Kentu, por. M. Mourre, Dictionnaire encyclopédique d'histoire, Paris 1978, 670.

169 Por. Epistulae VI 5; VI 58 i 60; VIII 4; IX 213 i 214; XI 46; XI 48 i 49; XIII 5.

170 Teodolinda byla córką Garibalda, króla Bawarii, i żoną Autaryka, króla Longobardów. Po jego śmierci, w 590 r. wyszła za mąż za jego następcę - Agilulfa. Zasłużona w kwestii przejścia Longobardów z arianizmu na katolicyzm, por. E. Malaspina, Teodolinda, DPAC II 3370.

${ }^{171}$ Por. Epistulae IV 4 i 33; V 52 (omyłkowo wstawiony przez kopistów po raz drugi list IV 33); IX 68; XIV 12.

${ }^{172}$ Por. F.E. Consolino, Il papa e le regine: pottere femminile e politica ecclesiastica nell'epistolario di Gregorio Magno, w: Gregorio Magno e il suo tempo, SEA 33, Roma 1991, 225-249.

173 Por. Epistulae I 5; VII 23; XI 27.

174 Por. tamże VII 27. 
Chcąc scharakteryzować relacje naszego autora z jego możnymi korespondentkami, możemy powiedzieć, że kobieta ma jednak ograniczony wpływ, żadna nie znajduje się u steru rządów, raczej towarzyszy mężowi. Wyjątek stanowi Brunhilda, która po śmierci męża, Sigiberta I († 575) i syna, Childeberta II $(† 595)$, rządziła jako regentka, w imieniu dwóch nieletnich wnuków, Teodeberta II (†612), króla Austrazji oraz Teodoryka II (†613), króla Burgundii i Austrazji. ${ }^{175}$

$\mathrm{Za}$ to odnotowujemy ważną pozycję kobiety na płaszczyźnie wiary i życia Kościoła: kobieta ewangelizuje męża, czego przykłady mamy w działalności Berty i Teodolindy; wspiera misje Kościoła, jak wspomniana Berta i Brunhil$\mathrm{da}^{176}$; wspiera papieża zarówno w kwestii dyscypliny eklezjalnej ${ }^{177}$, jak i pomocy duchownym $^{178}$; stara się o pokój między narodami ${ }^{179}$. Smiało możemy rzec, że jednym z filarów powstającej właśnie chrześcijańskiej Europy są kobiety.

Ze swej strony św. Grzegorz traktuje kobiety godnie, z troską pasterską. Dotyczy to nie tylko kręgów dworskich, Grzegorz darzy przyjaźnią i szacunkiem np. Antoninę i Barbarę, córki swego dawnego przyjaciela Wenancjusza, zresztą dawnego mnicha, co mówi samo za siebie, szczególnie jeśli zważymy na jego podejście do małżeństw osób ze stanu zakonnego. Zresztą tę listę można ciągnąć jeszcze bardzo długo. Grzegorz bowiem jest otwarty na sprawy socjalne kobiet, na ich ubóstwo i problemy duchowe ${ }^{180}$.

Obok powyższych aspektów, z pism Grzegorza wyłania się obraz kobiety religijnej, oddanej modlitwie ${ }^{181}$ i ofiarnej ${ }^{182}$. Kobiecie, przynajmniej z wyższych sfer, nie była obca lektura Biblii i pobożnych ksiąg ${ }^{183}$. Nie są jej również obce pielgrzymki do świętych miejsc ${ }^{184}$. Kobieta wreszcie to także fundatorka klasztorów $^{185}$ i kaplic ${ }^{186}$, człowiek miłosierdzia, wspierający ubogich ${ }^{187}$.

Integralną częścią społeczeństwa VI wieku była grupa niewolników ${ }^{188}$. W Kościele, jak zapewnia A. Hamman, niewolnicy mieli te same prawa, co

${ }^{175}$ Rządy te skończyły się w sposób dla Brunhildy okrutny, w wyniku intryg. Pokonana w bitwie pod Châlons-sur-Aisne, zdradzona, wystawiona na pośmiewisko i skazana na śmierć, zmarla wleczona przez konia, w 613 r. Zob. Fredegarius, Chronica, 42.

176 Por. Epistulae VI 60; VIII 4; XI 48.

177 Por. tamże VIII 4; IX 214; XI 49.

${ }^{178}$ Por. tamże VI 5; XIII 5.

179 Por. tamże IX 68.

180 Por. J.Z. Lachowicz, La mujer en el pensamiento de San Gregorio Magno (540-604), w: Excerpta e dissertationibus in sacra theologia 43, Pamplona 2002, 224-248.

${ }^{181}$ Por. Epistulae VII 22 i 33; XI 59; XIII 24 i 33.

182 Por. tamże XI 27.

183 Por. tamże VII 23; XI 59.

184 Por. tamże IV 44.

185 Por. tamże I 46 i 50; III 58; IV 8; IX 171 i 233; X 1.

186 Por. tamże II 11; III 58; IX 181 i 182.

187 Por. tamże XII 2.

188 Por. A. Steinmann, Sklavenlos und alte Kirche, München - Gladbach 1922; S. Talamo, La schiavitù secondo i Padri della Chiesa, Roma 1927. 
wolni: przystępowali do sakramentów, mogli obejmować urzędy, lącznie z biskupstwem $^{189}$. Ta rzeczywistość nie jest nieznana św. Grzegorzowi ${ }^{190}$. Jeśli mówimy o kobiecie, to warto zauważyć, iż chociaż znajdujemy u niego referencję do „niewolniczej skazy” (macula servilis), to również spotykamy szacunek $\mathrm{w}$ stosunku do byłych niewolnic ${ }^{191} \mathrm{i}$ intencje pomocy do pozostających ciągle w stanie niewolniczym ${ }^{192}$. Grzegorzowa chęć wsparcia niewolnicy, a nawet jej wyzwolenia, okazuje się tym większa, jeśli chce ona wstąpić do klasztoru ${ }^{193}$. I w ten sposób wracamy do najlepszego w jego oczach stanu życia kobiety.

W toku powyższego wywodu, mam nadzieję, ukazał się nam obraz kobiety utkany $z$ dwóch wątków obecnych w dziele św. Grzegorza: teoretycznych rozważań nad znaczeniem i symboliką kobiecych postaci oraz praktycznych odniesień do kobiet współczesnych temu wybitnemu myślicielowi schyłku okresu patrystycznego.

Obraz kobiety w teorii to głównie symbol i alegoria. Widzimy przez jej pryzmat Kościól, ludzką duszę, obraz cnót, ale też i ludzkich przypadłości. Kim jest zatem owa kobieta w wizji Grzegorza? Obrazem słabości, kimś odrobinę poniżej mężczyzny. Skrzywdziłby jednak ów VI wiek, kto by się zatrzymał tylko na tym. Bo kobieta to też obraz siły i determinacji, jak pokazuje zachwyt Grzegorza nad postaciami męczennic. To ktoś, kogo należy kochać i o kogo należy się martwić. To osoba żyjąca zarówno we wspólnocie monastycznej, jak i we wspólnocie małżeńskiej, także $\mathrm{z}$ duchownymi, co przeczy normom $\mathrm{i}$ intencjom papieskim. To też wdowa otoczona opieką Kościoła. Dobrze - ta droga zakonna jest jednak lepsza w oczach człowieka tamtego czasu. W oczach naszego autora, bo raczej nie tych mniszek, które uciekały z klasztorów. Kwestii tej jednak nie należy widzieć jako próby podporządkowania kobiety Kościołowi. Tak samo rzecz ma się z mężczyznami. Odpowiedzią tu jest troska o życie wieczne, tyle że poszukiwane na miarę stereotypów tamtej epoki.

Kobieta VI wieku to cesarzowa i królowa, nie pozbawiona wpływu na politykę i obraz świata; to kobieta wyższych sfer, może podporządkowana, ale jednak mająca wiele do powiedzenia; to kobieta wykształcona i pobożna, znająca zarówno religijne praktyki, jak i radząca sobie w życiu codziennym. To osoba czasem hojna i otwarta na potrzeby innych, czasem trudna i problematyczna. Bywa, że kobieta $\mathrm{z}$ dzieł Grzegorza to także niewolnica.

Kobieta VI wieku to osoba grająca ważną rolę w Kościele. Oczywiście na miarę pozycji i możliwości. To człowiek modlitwy, to ktoś, kto wspiera rozwój

${ }^{189}$ Por. A. Hamman, Schiavitù, DPAC II 3111-3113.

190 Por. E. Benedetti, S. Gregorio Magno e la schiavitù, Roma 1904.

191 Por. Epistulae VII 41.

192 Por, tamże IV 12.

193 Por. tamże III 39 
Kościoła, dba o ewangelizację, wychowuje religijnie dzieci, kto sam dąży do zbawienia i pomaga $w$ tym także innym.

Grzegorz zostawia nam obraz w miarę szeroki, a jednak nie całościowy, ale któż potrafi ukazać całościowy obraz tak rozległego zagadnienia?

\title{
LE LIEU ET LE RÔLE DE LA FEMME DANS LA VIE ET LA PENSÉE DE SAINT GRÉGOIRE LE GRAND
}

\author{
(Résumé)
}

La réflexion sur le rôle de la femme dans le monde et dans l'Église occupe aujourd'hui la place très importante. Mais pour recevoir une image pleine de ce problème, il faut toujours se rapporter à l'histoire. Nous avons choisi un personnage de la rencontre des époques : de l'antiquité chrétienne et du moyen âge, un grand évêque de Rome, saint Grégoire I.

Au niveau de la théorie, spécialement dans les commentaires bibliques, dans les homélies et les dialogues, nous trouvons une image de la femme biblique, la femme de l'hagiographie et de la femme des légendes pieuses. Successivement nous rencontrons la sainte Marie et des autres femmes bibliques qui servent comme exemples de la vie chrétienne directement ou de manière symbolique et forment des allégories de l'Église, de l'âme humaine et des vertus, mais aussi de la faiblesse.

D'un autre côté, spécialement dans la correspondance, saint Grégoire nous parle sur les différents chemins de la vie féminine, comme la vie monastique, familiale ou veuvage. Dans les yeux de premier pape moines le plus important lieu occupe la vie monastique. Un espace suffisant l'intercesseur du célibat consacre aussi pour le problème des relations entre des femmes et des écclésiastiques. Dans l'hérédité litteraire de Grégoire nous disposons aussi d'une grande collection de lettres à impératrices et reines du temps grégorien, qui nous montre une image riche de la femme noble et de son influence dans la societé.

Grégoire nous montre le problème de la femme dans les différentes circonstances, de la vie quotidienne et spirituelle, dans le niveau social plus haut et plus bas. L'image de la femme qui sort des oeuvres grégoriennes est abondante mais n'est pas complète. Il faut dire aussi que cette image est souillée par la pensée de ce temps. Malgré tout c'est une image positive et bonne. L'oeuvre grégorienne nous montre une synthèse intéressante et importante tant pour le moyen âge que pour notre temps. 